\title{
Teknologi Tepat Guna dan Penambahan Alat Produksi untuk Meningkatkan Produktivitas Usaha Bolu Labu
}

\author{
Made Satria Wibawa ${ }^{1, *}$, Nyoman Ayu Nila Dewi ${ }^{2}$, Ni Luh Putu Ririn Trisnayanti ${ }^{3}$ \\ 1,2,3 Institut Teknologi dan Bisnis STIKOM Bali, Indonesia \\ ${ }^{1}$ satria.wibawa@stikom-bali.ac.id*; ${ }^{2}$ nila@stikom-bali.ac.id \\ * corresponding author
}

ARTICLE INFO

\section{Keywords}

Production Equipment;

Community Service;

$U K M$;

Cake

\begin{abstract}
The home industry for food has now begun to develop, seeing so many types of cakes and snacks that sell products to traditional markets. This internal community service activity will carry out community service activities for internal community service activities. Existing requirements where the use of partner equipment is still quite minimal while the oven used is still quite small with 1 baking capacity. The level of understanding of partners in the use of technology is still very minimal by looking at the low promotion and marketing media carried out by partners. The current partner marketing process is entrusted to traditional markets around the partner location. Other marketing is done by entrusting products in schools in partner locations. Products that are partnered by partners do not contain the packaging labels and business partner information. From these problems, the internal community service activities will provide assistance in the form of an oven with a capacity of 3-4 oven baking pan to improve the production process. Providing packaging labeling training to enhance partners' knowledge of the use of technology. Training in the use of technology using online marketing media. Utilization of this technology is used to market products produced through online media.
\end{abstract}

\section{PENDAHULUAN}

Pengabdian masyarakat internal merupakan salah satu kegiatan tri dharma perguruang tinggi yang wajib dilakukan oleh dosen untuk memberikan ilmu pengetahuan dan membuka wawasan masyarakat terhadap berbagai aspek. Salah satu kegiatan pengabdian masyarakat yang dapat dilakukan adalah penerapan teknologi dalam membantu mitra di berbagai aspek seperti pemanfaatan teknologi dalam produksi, pemanfaatan dalam sosial dan pemanfaatan dalam dunia pendidikan. Pada saat ini masyaralat pada situasi yang membutuhkan banyak invoasi terhadap produk-produk UMKM yang dihasilkan untuk memenuhi kebutuhan pelanggan. Dalam pelaksanaan nya selera masyarakt selalu berubah-ubah sehingga para pelaku usah akecil menengah diharapkan mampu berkreasi untuk menghasilkan produk-produk yang lebih baik dari segi kualitas maupun kuantitas. Dibutuhkan banyak sekali inovasi untuk memberikan pemahaman dan kemampuan mitra dalam meningkatkan kebutuhan selera masyarakat. Kesulitan yang terjadi pada mitra produksi makanan yang harus memberikan inovasi yang lebih cepat untuk dapat memberikan cita rasa yang berbeda.

Kegiatan pengabdian masyarakat ini akan membantu salah satu mitra yang memproduksi olahan kue berupa bolu dengan beraneka jenis bolu. Kondisi yang terjadi dilapangan saat ini adalah dimana mitra yang berlokasi di Jalan Cekomaria Gang I merupakan mitra pengabdian masyarakat internal yang memproduksi aneka kue bolu yang dipasarkan pada pasar trdisional dan sekolahsekolah yang ada di lokasi tempat produksi mitra. Usaha kue bolu sudah ditekuni sejak tahun 2015 sampai saat ini. Mitra memproduksi kue bolu setiap harinya sekitar 5-8 loyang yang dijual di sekitar lokasi mitra. Kendala yang terjadi adalah mitra mengalami kelemahan dalam memproduksi kue dimana oven yang dimiliki saat ini menampung 1 buah Loyang dengan adonan. Untuk 
memproduksi dengan skala yang cukup banyak mitra harus bergantian dan menunggu sampai dengan adonan pertama selesai di oven. Resiko dari proses ini dimana mitra sering mengalami bahan baku yang telah diolah tidak dapat di gunakan kembali karena waktu tunggu yang cukup lama.

Pemesanan dengan jumlah besar juga mengalami kendala dimana mitra harus mengerjakan dengan jumlah kecil dikarenakan keterbatasan dari alat produksi. Melihat kondisi tersebut maka dalam kegiatan pengabdian ini akan dilakukan kegiatan penambahan alat produksi berupa oven dengan kapasitas produksi yang cukup besar yang dapat menampung kurang lebih 5-6 oven. Alat produksi ini diberikan agar mitra dapat memproduksi pesanan yang cukup banyak, untuk memenuhi kebutuhan masyarakat.

Tingkat pengetahuan mitra yang cukup minim dengan penggunaan teknologi dilihat dari produk yang dimiliki mitra tidak terdapat informasi tentang usaha mitra seperti informasi nama usaha dan no tlp mitra. Kegiatan pengabdian yang dapat diberikan adalah pelatihan ke mitra untuk labeling kemasan untuk mempercepat informasi sampai kemasyarakat. Kendala yang terjadi mitra belum mengetahui informasi apakah ada pemesanan dari masyarakat tentang produk kue yang dihasilkan.

Dari permasalahan tersebut maka dalam kegiatan pengabdian ini akan memberikan alat untuk meningkatkan jumlah produksi berupa oven. Tujuan kegiatan ini agar memberikan kesejahteraan terhadap kondisi mitra. Adapun kondisi mitra seperti pada gambar dibawah ini:

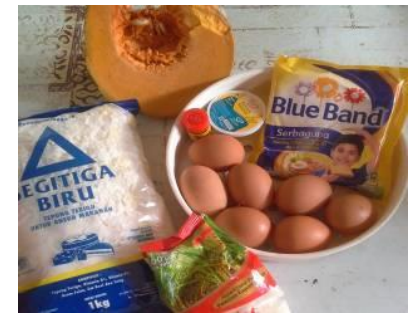

(a)

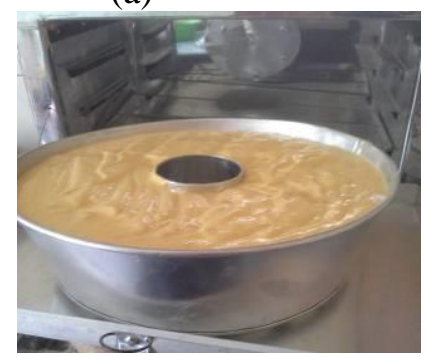

( c )

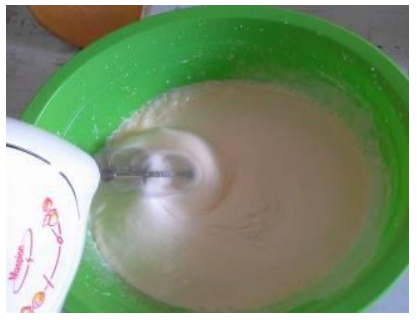

(b)

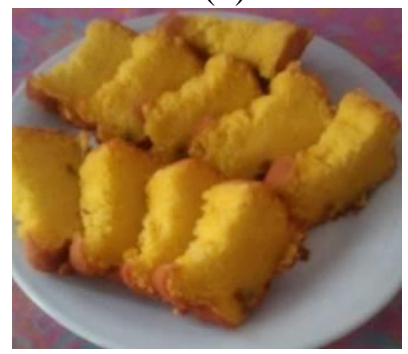

(d)

Gambar 1 Kondisi mitra (a,b,c,d)

Table 1. Tabel kondisi mitra

\begin{tabular}{|c|l|l|l|}
\hline No & Uraian & Mitra & Keterangan \\
\hline 1 & Kondisi produksi mitra & $\begin{array}{l}\text { 1. Minimnya jumlah alat } \\
\text { produksi } \\
\text { 2inimnya } \\
\text { pengetahuan mitra } \\
\text { dalam penggunaan } \\
\text { teknologi }\end{array}$ & $\begin{array}{l}\text { Minimnya pengetahuan mitra } \\
\text { dengan penggunaan teknologi }\end{array}$ \\
\hline 2 & $\begin{array}{l}\text { Kondisi pemasaran } \\
\text { mitra }\end{array}$ & $\begin{array}{l}\text { Mitra memesarkan di } \\
\text { pasar dan sekolah-sekolah } \\
\text { sekitar lokasi mitra }\end{array}$ & $\begin{array}{l}\text { Minimnya pengetahuan mitra } \\
\text { dalam penggunaan teknologi untuk } \\
\text { pemasran }\end{array}$ \\
\hline 3 & $\begin{array}{l}\text { Jumlah produksi mitra } \\
\text { per hari }\end{array}$ & $\begin{array}{l}\text { 2-3 loyang / hari } \\
\text { disesuaikan dengan jumlah pesanan }\end{array}$ \\
\hline 4 & $\begin{array}{l}\text { Jumlah pendapatan } \\
\text { mitra dalam 1 bulan }\end{array}$ & $\begin{array}{l}\text { Rp 1.000.000 - Rp } \\
1.500 .000 / \text { bulan }\end{array}$ & $\begin{array}{l}\text { Jumlah pendapatan meningkat } \\
\text { dilihat dari jumlah pesanan }\end{array}$ \\
\hline
\end{tabular}


Berdasarkan analisis situasi diatas maka permasalahan yang menjadi prioritas dalam kegiatan pengabdian masyarakat internal ini adalah penambahan alat produksi berupa oven yang dapat digunakan untuk proses produksi dengan jumlah yang lebih banyak. Pemahaman mitra dalam penggunaan teknologi masih cukup minim tentang penggunaan label kemasan maka dalam kegiatan pengabdian ini akan memberikan pelatihan labeling kemasan untuk memberikan informasi produk usaha yang dikerjakan mitra. Solusi yang ditawarkan dari permasalahan yang telah dijabarkan pada analisis situasi diatas adalah permasalahan jumlah produksi yang saat ini terjadi dimana kondisi mitra belum dapat memproduksi dengan jumlah banyak dan cepat karena alat produksi yang digunakan masih minim untuk itu solusi yang diberikan adalah penambahan alat produksi berupa oven yang nantinya dapat melakukan proses produksi jajan bolu 3-4 loyang untuk 1 kali oven. Permasalahan selanjutnya adalah minimnya pemahaman mitra tentang labeling kemasan yang digunakan pada produk untuk itu solusi yang ditawarkan adalah dengan memberikan pelatihan tentang labeling kemasan.

\section{PELAKSAAAN DAN METODE}

Rencana kegiatan pengabdian masyarakat ini melihat permasalahan yang ada akan dilakukan dalam waktu 8 bulan. Kegiatan yang menjadi prioritas adalah penambahan alat produksi untuk kegiatan pertama dan selanjutnya adalah labeling kemasan dan pemanfaatan teknologi untuk pemasaran produk.

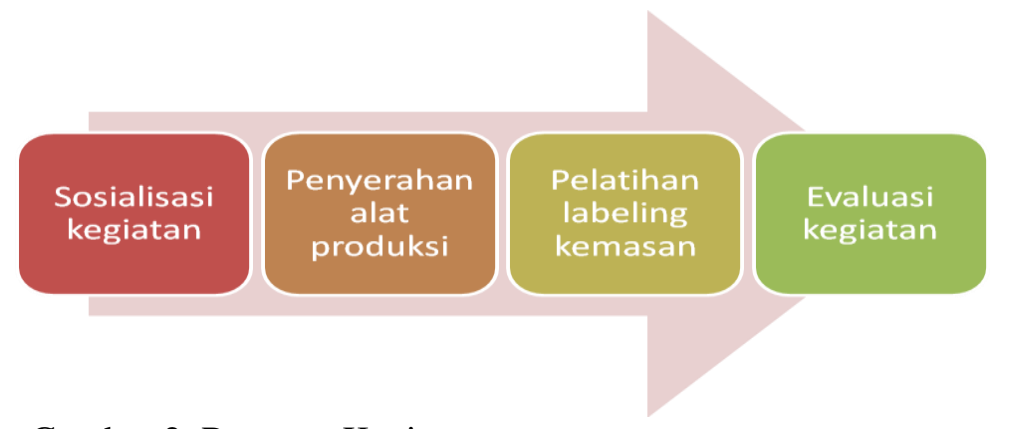

Gambar 2. Rencana Kegiatan

Tahapan kegiatan pengabdian masyarakat, dalam kegiatan pengabdian masyarakat ini memiliki beberapa tahapan dengan menentukan jadwal kerja agar kegiatan yang diajukan sesuai dengan tujuan maupun goal yang diinginkan. Dalam kegiatan pengabdian ada beberapa tahapan yang dilakukan oleh tim adapun kegiatan ini sebagai berikut:

\section{Sosialisasi kegiatan}

Tahapan pertama yang dilakukan adalah dengan melakukan kegiatan sosialisasi yang berfungsi untuk memberikan pengetahuan kepada mitra tentang pentingnya kegiatan pengabdian masyarakat. Kegiatan pengabdian masyarakat ini akan dilakukan oleh tim pengabdian masyarakat. Pengamatan dan penentuan jadwal kegiatan akan dilakukan di tahap sosialisasi untuk dapat menentukan agenda kegiatan yang dilakukan.

\section{Penyerahan alat produksi}

Tahapan kegiatan pengabdian masyarakat internal selanjutnya adalah penyerahan alat berupa oven yang dibutuhkan oleh mitra. Oven disini merupakan penambahan alat produksi mitra dimana kondisi mitra saat ini adalah mitra memiliki keterbatasan dalam alat produksi sehingga proses produksi membutuhkan waktu yang cukup lama.

3. Pelatihan labeling kemasan

Pelatihan labeling kemasan pada kegiatan pengabdian masyarakat ini digunkan untuk memberikan informasi yang berkaitan dengan usaha mitra. Labeling kemasan merupakan pelatihan yang dapat membantu mitra dalam meningkatkan pemasaran. Kegiatan pengabdian ini 
akan dilakukan selama kurang lebih 2-3 kali kegiatan. Kegiatan akan dilakukan oleh tim pengabdian masyarakat internal bersama mitra.

\section{Evaluasi kegiatan}

Evaluasi kegiatan merupakan tahap akhir yang akan dilakukan selama 8 bulan kegiatan. Evaluasi dilakukan untuk mengukur pemahaman dan kemampuan mitra terhadap kegiatan tersebut. Pengukuran akan dilihat dari berbagai aspek yaitu kegiatan produksi yang dievaluasi dari jumlah produksi, pemasaran yang dilihat dari kegiatan pormosi mitra.

\section{HASIL DAN PEMBAHASAN}

Pelaksanaan kegiatan pengabdian masyarakat akan dilaporkan pada sub bab ini, pelaksanaan pengabdian masyarakat yang dilakukan untuk tahap pertama yang dapat dilaporkan adalah penambahan alat produksi. Dari permasalahan yang dialami oleh mitra dan telah disepakati bahwa kegiatan ini menambah alat produksi oven dengan ukuran yang lebih besar dimana dapat menampung 2 oven untuk 1 kali pembakaran. Kompor yang digunakan untuk menambah alat produksi untuk mempercepat proses produksi bolu labu. Kegiatan pertama dilakukan dengan agenda sosialisasi ke mitra untuk membahas kegiatan pengabdian masyarakat, kegiatan kedua adalah dengan survei alat produksi yang akan diberikan oleh pengusul, ketiga adalah penyerahan alat produksi serta penjelasan penggunaan alat produksi. Dan kegiatan terakhir adalah evaluasi peningkatan jumlah produksi. Evaluasi peningaktan jumlah produksi dilakukan oleh pengusul untuk mengukur waktu pengerjaan dengan waktu yang dibutuhkan serta jumlah bolu yang dapat di produksi dalam 1 kali pengerjaan. Adapun pembahasan di masing-masing kegiatan adalah sebagai berikut:

1. Sosialisasi kegiatan:

Sosialisasi kegiatan pengabdian masyrakat selalu dilakukan di awal kegiatan untuk menginformasikan kepada mitra tentang pentingnya kegiatan pengabdian masyarakat. Kegiatan ini dilakukan 1 hari kegiatan dan kegiatan ini dilakukan oleh ketua dan anggota pengusul. Dalam kegiatan ini memberikan penjelasan tentang pengabdian masyarakat, melihat proses produksi sehingga dapat mendiskusikan alat yang akan diberikan. Pada kegiatan ini mitra membutuhkan oven besar dengan kompor untuk proses produksi. Untuk dapat membantu mitra dan tidak membutuhkan biaya yang cukup besar dalam proses produksi dibandingkan dengan kompor listrik. Alas an mitra memilih oven kompor untuk biaya produksi yang bias ditekan dibandingkan dengan oven listrik membutuhkan biaya yang cukup besar dalam penggunaan listrik.

2. Survei alat produksi:

Setelah kegiatan sosialisasi yang dilakukan dan telah disepakati maka dalam kegiatan ini mitra dan pengusul melakukan survei alat produksi. Kegiatan ini dilakukan oleh mitra, ketua pengusul dan anggota pengusul yang melakukan survei alat produksi.

3. Penyerahan alat produksi:

Kegiatan penyerahan alat produksi dilakukan oleh tim pengusul serta mitra. Kegiatan ini dilakukan 1 hari kegiatan dengan penyerahan alat produksi dan penggunaan alat produksi yang diberikan adapun kegiatan yang telah berlangsung serah terima barang yang diberikan kepada mitra sesuai dengan kebutuhan mitra. Serah terima barang sekaligus dengan penandatanganan berita acara kegiatan dan berita acara pelaksanaan kegiatan pengabdian masyarakat. Dapat dilihat dalam gambar proses penandatanganan kegiatan pengabdian masyarakat. 


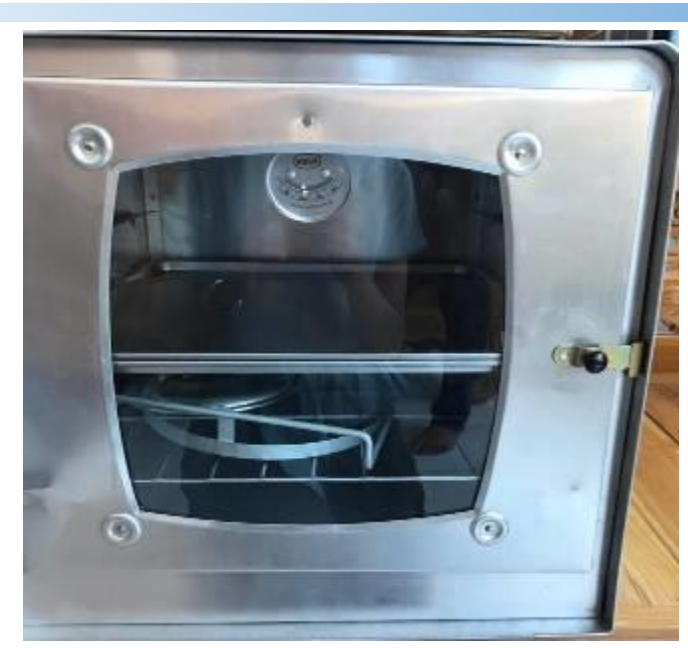

Gambar 3 Oven hock dengan 2 loyang

Gambar 3 merupakan alat yang diberikan kepada mitra, dimana oven ini diguankan untuk memproduksi bolu dengan 2 loyang. Oven ini menggunakan kompor dalam memproduksi bolu labu. Adapun spesifikasi alat ini adalah sebagai berikut:

1. Berat: $7.1 \mathrm{~kg}$

2. Oven aluminium

3. Dimensi : H (40.8) W (40) D (49) cm

4. Temperatur oven : ada

5. Menggunakan kompor

Oven kompor ini diberikan ke mitra untuk dapat membantu proses produksi dimana saat ini mitra menggunakan oven 1 loyang dengan kendala jika mendapat pesanan yang dengan jumlah besar tidak dapat diselesaikan dengan segera karena membutuhkan penyelesaian per tahap dan per Loyang. Maka dalam kegiatan pengabdian masyarakat ini menambah alat produksi berupa oven dengan 2 loyang.

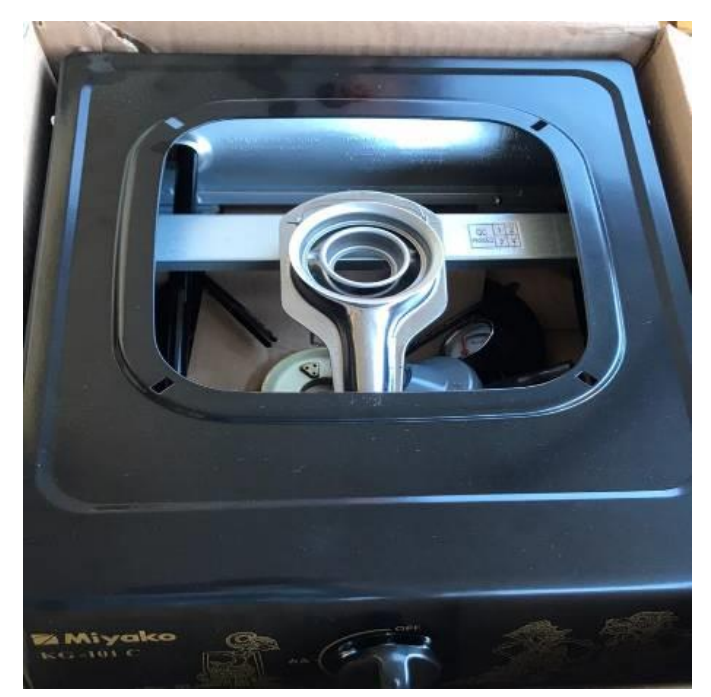

Gambar 4. Kompor Miyako

Gambar 4 merupakan penambahan alat produksi kompor 1 tungku yang dapat digunakan untuk produksi bolu labu. Permasalahan sebelumnya dimana mitra telah memiliki oven dan kompor namun alat produksi yang dimiliki masih cukup minim, dengan diberikan oven proses produksi bias dilakukan namun kendala pada saat memasak dikarenakan alat yang membutuhkan tempat yang cukup luas, maka dari itu dalam kegiatan pengabdian ini menambahkan alat produksi kompor 1 tungku untuk produksi dengan oven 2 loyang, agar proses produksi dapat ditingkatkan. 




Gambar 5 Regulator kompor

Gambar 5 merupakan regulator untuk kompor ke tabung gas yang diberikan pada saat kegiatan pengabdian masyarakat. Serah terima barang yang dibutuhkan oleh mitra yaitu ibu Ieus Hendrawati, alat diserahkan oleh pengusul dan diberikan ke mitra untuk dapat meningkatkan jumlah produksi bolu labu. Evaluasi kegiatan pengabdian merupakan tahapan akhir dalam agenda kegiatan pengabdian masyarakat. Evaluasi kegiatan pengabdian masyarakat ini adalah dengan melakukan pengukuran jumlah produksi yang dapat diselesaikan dengan waktu penyelesaian produk. Adapun data evaluasi kegiatiatan produksi adalah sebagai berikut:

Table 2 Data evaluasi jumlah produksi

\begin{tabular}{|l|l|l|}
\hline No & $\begin{array}{l}\text { Jumlah produksi sebelum } \\
\text { kegiatan pengabdian }\end{array}$ & $\begin{array}{l}\text { Jumlah produksi setelah } \\
\text { kegiatan pengabdian }\end{array}$ \\
\hline 1 & 2-3 loyang/hari & 4 loyang / hari \\
\hline
\end{tabular}

Tabel 2 adalah data evaluasi yang dilakukan pada kegiatan pengabdian masyarakat. Data di dapat dari proses produksi yang dilakukan pada 1 hari produksi pengerjaan, pada tahapan selanjutnya akan dilakukan evaluasi lebih lanjut. Perbandingan dari sebelum dilakukan pengabdian dan setelah dilakukan pengabdian adalah penambahan jumlah produksi untuk bolu sebanyak 1 loyang bolu.

Table 3 Data waktu produksi

\begin{tabular}{|l|l|l|}
\hline No & $\begin{array}{l}\text { Waktu pengerjaan sebelum } \\
\text { kegiatan pengadian } \\
\text { masyarakat }\end{array}$ & $\begin{array}{l}\text { Waktu pengerjaan setelah } \\
\text { kegiatan pengabdian } \\
\text { masyarakat }\end{array}$ \\
\hline 1 & 30 menit/1 loyang & 30 menit / 2 loyang \\
\hline
\end{tabular}

Tabel 3 merupakan data untuk proses produksi yang dilakukan oleh mitra. Dimana data ini diambil dalam 1 proses produksi. Data kegiatan pengabdian menunjukan bahwa proses produksi dilakukan selama 30 menit sebelum kegiatan dengan menghasilkan 1 loyang maka setelah kegiatan pengabdian mendapatkan waktu 30 menit untuk 2 loyang bolu.Pelaksanaan kegiatan selanjutnya pada tahap II ini adalah pelatihan label kemasan dan pelatihan media sosial yang telah dilakukan oleh tim pengabdian masyarakat, adapun pembahasan hasil kegiatan pengabdian adalah sebagai berikut:

Pelaksanaan kegiatan pengabdian tahap 2 ini adalah kegiatan labeling kemasan untuk pemasaran produk bolu labu yang dihasilkan mitra. Kegiatan pengabdian ini bertujuan untuk memberikan pengetahuan ke mitra tentang penggunaan teknologi dalam memasarkan produk. Kegiatan pengabdian ini berlangsung selama 3 hari untuk melatih mitra membuat desain label produk. Kondisi saat ini dimana mitra memproduksi bolu labu dengan memasarkan pada toko-toko, sekolah, dan pasar disekitar lokasi mitra. Kegiatan pengabdian tahap II ini dimulai dari persiapan kegiatan pengabdian sampai dengan evaluasi kegiatan, adapun agenda yang telah dirancang oleh tim pengabdian beserta mitra adalah seperti tabel dibawah ini: 
Table 4 Jadwal Kegiatan

\begin{tabular}{|l|l|l|}
\hline No & Kegiatan & Hari \\
\hline 1 & Rapat kegiatan pengabdian & 2 hari \\
\hline 2 & Sosialisasi label kemasan ke mitra & 1 hari \\
\hline 3 & Rapat tim persiapan desain & 2 hari \\
\hline 4 & Pelatihan desain label & 3 hari \\
\hline 5 & Evaluasi kegiatan & 1 hari \\
\hline
\end{tabular}

Pada sub bab ini akan menjelaskan kegiatan pengabdian masyarakat yang telah dikerjakan mulai dari tahap persiapan sampai dengan pembahasan dan evaluasi kegiatan pengabdian masyarakat. Melihat kondisi mitra dimana pengetahuan mitra tentang teknologi masih sangat minim dilihat dari produk yang dipasarkan masih belum memiliki label kemasan. Mitra memiliki kendala dalam pemasaran produk, beberapa kali mitra mendatangi pasar dan toko kue yang ada di sekitaran lokasi tempat tinggal mitra untuk menjual kue bolu yang telah di produksi. Permasalahan yang sering ditemui oleh mitra adalah konsumen yang menginginkan produk itu kembali harus datang ke pasar, sekolah atau ke toko tempat mitra menjual produk, konsumen tidak dapat menguhubungi mitra karena produk tidak memiliki informasi usaha bolu labu. Kegiatan pengabdian dimulai dari tahap persiapan pelatihan desain dimana tim melakukan rapat untuk persiapan materi desain yang akan digunakan dan tools yang akan digunakan untuk pelatihan. Setelah tahap persiapan tim pengabdian melakukan sosialisasi ke mitra terkait dengan pelatihan yang akan diberikan selama kurang lebih 3 hari pelatihan untuk desain label kemasan.

Tahap sosialisasi ini dilakukan untuk menentukan waktu pelatihan desain label produk, waktu pelaksanaan dan peserta yang akan mengikuti kegiatan tersebut. Selain tahap sosialisasi tim juga memberikan penyuluhan tentang manfaat dari label kemasan untuk produk, dimana label yang akan dikerjakan nanti memberikan manfaat dalam memasarkan produk dengan harapan informasi tentang produk mitra menjadi meluas dan lebih banyak lagi masyarakat yang mengetahui informasi dari produk tersebut. Konsumen yang menginginkan produk tersebut dapat menghubungi mitra dan manfaat lainnya yaitu jumlah produksi meningkat, pemasukan mitra juga bertambah. Kegiatan tahap II ini berkaitan dengan kegiatan tahap I dimana pada tahap sebelumnya tim memberikan penambahan alat produksi dengan harapan mitra dapat memproduksi dengan jumlah yang lebih banyak. Penambahan jumlah produksi diharapkan dapat terjadi dari pemasaran produk dengan label kemasan yang tercantum dalam kemasan bolu labu. Adapun pelatihan desain yang dilaksanakan adalah sebagai berikut:

\section{Tahap pertama}

Pada tahap pertama tim menentukan tools yang digunakan dalam pelatihan desain logo yaitu menggunakan canva.com agar mudah digunakan oleh mitra nantinya dan mudah untuk melakukan redesain logo produk. Selain itu tools ini bersifat online sehingga mitra tidak perlu menyediakan perangkat keras dengan spesifikasi tinggi.

2. Tahap kedua pelatihan

Pada tahap kedua dalam pelatihan adalah menentukan nama produk yang akan ditampilkan dalam logo, nama produk yang telah disepakati mitra adalah "labo's cake". Nama logo ini yang akan digunakan oleh mitra memasarkan produk bolu labu.

3. Tahap ketiga pelatihan

Pada tahap ini adalah tampilan desain logo yang akan digunakan pada produksi bolu labu. Adapun logo yang dihasilkan pada saat latihan adalah sebagai berikut: 


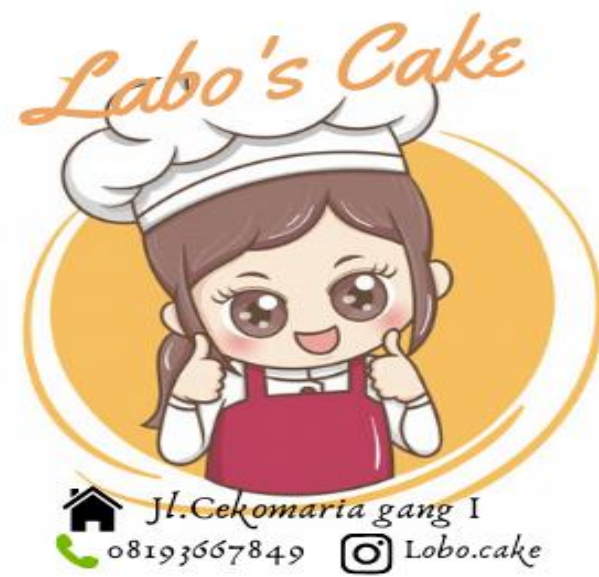

Gambar 6 Desain label produk

Gambar diatas merupakan hasil kegiatan pengabdian masyarakat yang telah dilakukan dengan menghasilkan logo dan berisi informasi tentang nama usaha dan informasi no tlp yang dapat dihubungi untuk memesan kembali.

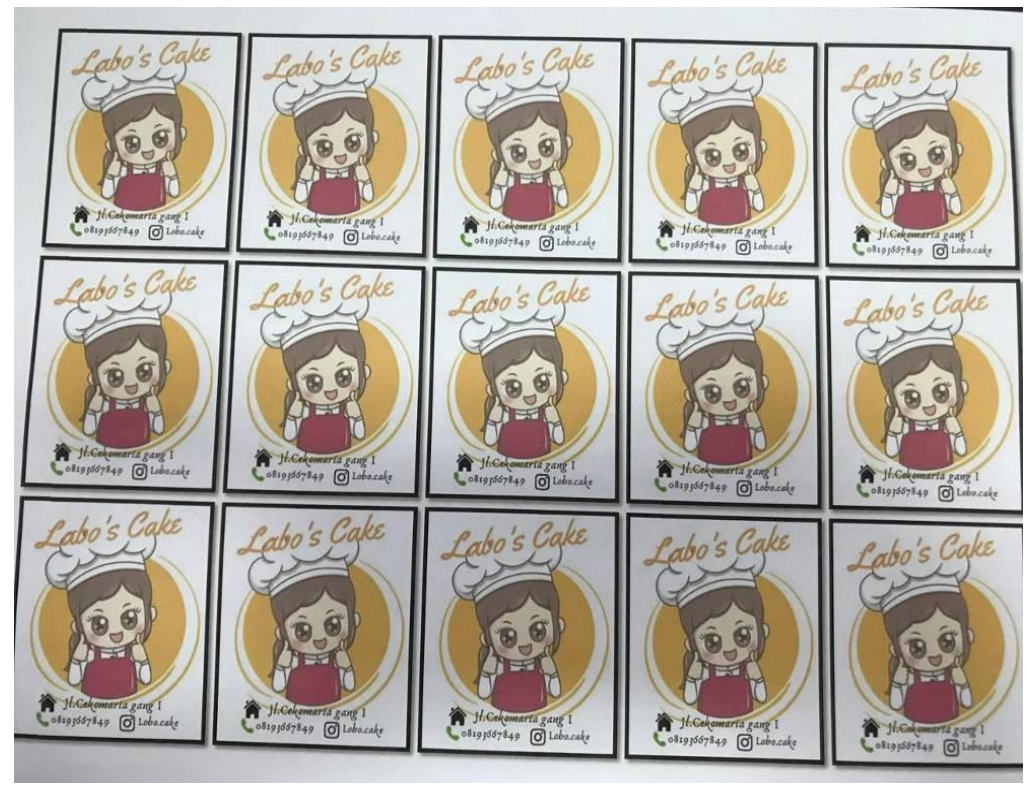

Gambar 7 Cetak label

Gambar berikut merupakan hasil cetakan yang siap akan digunakan untuk memasarkan produk.

\section{PENUTUP}

Pada bagian ini akan memberihak kesimpulan dari hasil kegiatan pengabdian yang telah berlangsung adapun kesimpulan dan saran adalah sebagai berikut:

\section{Simpulan}

Kesimpulan yang dapat diambil dalam kegiatan ini adalah, permasalahan yang dialami mitra sudah dapat diselesaikan dengan penambahan alat produksi untuk meningkatkan jumlah produksi bolu labu. Kegiatan pengabdian masyarakat sangat bermanfaat dan mitra memikili pengetahuan tentang kegiatan pengabdian masyarakat. Dengan alat produksi yang bertambah jumlah produksi dapat ditingkatkan.

\section{Saran}

Kegiatan ini masih memiliki kekurangan yang dapat menjadi saran dalam kegiatan pengabdian masyarakat ini adalah perlu dilakukan pelatihan variasi produk oleh tim ahli makanan, guna 
memberikan variasi produk yang dapat di pasarkan oleh mitra. Agar dapat memberikan wawasan ke mitra tentang produk yang menjadi minat masyarakat saat ini.

\section{Ucapan Terima Kasih}

Terimakasih kami ucapkan kepada Bagian LPPM yang telah membantu dokumen-dokumen dalam kegiatan pengandian yang telah dilaksanakan. Terimakasih juga kami ucapkan kepada mitra yang telah memberikan waktu dan menyediakan tempat untuk keberlangsungan kegiatan pengabdian masyarakat ini.

\section{DAFTAR PUSTAKA}

Ekayani,Masdarini,Sudria,.2014.,’Pelatihan Pengembangan Produk Jajanan Cake Berbahan Dasar Umbi-Umbian Sebagai Kontribusi Program Diversifikasi Konsumsi Pangan Di Desa Petandakan Buleleng".,Universitas Pendidikan Ganesha.

Sudewi Yogha dan Nurani A.S. 2010. Potensi Tepung Singkong Sebagai Bahan Industri Kreatif Kuliner Boga. Makalah Prosiding ISBN 978-60296174-0-5.Universitas Negeri Malang.

Maryama,Siti.,Yandri,Pitri., Istimal, Imal.2018.," Pelatihan Pembuatan Packaging Dalam Upaya Meningkatkan Penjualan Produk UMKM di Kota Tanggerang Selatan. Prosiding Sembadha 2018, Volume 01, Edisi 01. Poliklinik Keuangan Negara STAN.

Resmi, N., dan Wismiarsi, T., 2015. Pengaruh Kemasan Dan Harga Pada Keputusan Pembelian Minuman Isotonik. Jurnal Manajemen dan Bisnis Sriwijaya Vol.13 No.1 Maret 2015 